\title{
The impact of colonisation on te reo Māori: A critical review of the State education system
}

\begin{abstract}
Languages die because they are no longer spoken. This happens because their speakers die out without passing them on to the next generation. Only rarely is this because of the extinction of an entire society or race. Usually it happens because from generation to generation (it takes only three or four) the speakers shift to another language. Languages do not die natural deaths. They do not fade away without outside influence. Languages are killed by other languages (Bell 1991: 67).
\end{abstract}

In the study of Māori language decline one must critically review the New Zealand State education system, including a discussion of the key events and legislation in the history of Pākehā colonisation and assimilation in Aotearoa/New Zealand. This will form the chronological map of the deterioration of the status of the Māori language.

'We inhabit language and language inhabits us. A main means of communication, we can't think without it' (Tonkin 1995: 75). This statement by Tonkin along with the quotation that opens this paper illustrate the force and power of language. These quotations provide a context for the information that follows.

By 1979, merely 139 years after the signing of Te Tiriti o Waitangi (The Treaty of Waitangi) ${ }^{1}$, the loss of te reo Māori was

1 Te Tiriti o Waitangi (The Treaty of Waitangi) was signed on the 6th of February 1840. It was meant to establish a partnership between 
so great that it was believed it would suffer language death (Walker 1990: 147-148). This can be attributed to colonisation and the State policy of assimilation which eroded the status of the language. From its inception, the New Zealand Government has continually passed legislation that has been detrimental to the Māori language and furthered the Government's agenda of cultural assimilation and language domination. The mechanism of the Government's agenda of assimilation and language domination was the State education system. This was, therefore, the primary cause of Māori language loss. According to McCarthy, 'Māori have a long history of experiencing assimilative policies and practices which have been detrimental to the overall well-being of Māori, as evidenced in the language, culture and identity losses of many' (McCarthy 1997: 30). In some cases the legislation regarding the State education system can be directly linked to language loss. However, in many cases the education system has negatively affected te reo Māori indirectly through aspects of Eurocentric education. These include assimilation, cultural invasion, cultural subordination, language domination, hegemony, the curriculum, class structures, racism, meritocracy, intelligence testing, and negative teacher expectations. To fully understand how this tragedy has occurred, it is important to understand how the New Zealand State education system has evolved and what aspects of education may have negatively affected te reo Mãori.

the British Crown and Māori as the Indigenous people of Aotearoa/New Zealand. Since its signing it has been the focus of controversy and scrutiny due mostly to the fact that two versions of the Treaty were produced. The Māori text, which was signed by both Māori and the Crown, was translated from the English text by a Pākehā missionary. However, the translation was not at all a correct interpretation of the English text. It is the English text which has been used by the Crown as the definitive version and this is the cause of contention to this day between Māori and the Crown. 


\section{Te Tiriti o Waitangi}

Te Tiriti o Waitangi, one text written in te reo Mãori and the other in English, was first signed on 6 February 1840, between the rangatira Māori of Aotearoa/New Zealand and the representatives of the Crown. Māori have always considered Te Tiriti o Waitangi as a charter that was supposed to be the basis of a national dual planning system, incorporating both Māori and Pākehā values into every aspect of decision-making in Aotearoa/New Zealand (Glynn 1998: 3). Furthermore, this charter was also signed under the pretence that it would act to protect Māori rights. 'To many Maori people, the terms of the Treaty provided the ultimate protection for their way of life, their institutions, and their culture: they were mechanisms to protect their taonga' (Jackson 1988: 48).

However, the Crown failed, almost immediately, to honour the terms of Te Tiriti o Waitangi. 'The colonists had gained the benefit of the Treaty by being allowed to emigrate to this country under the British flag, but they were not willing to accept the burden of the bargain from which they had gained so much' (Temm 1990: 24). When Captain George Grey became governor of the colony, one of his first acts was the establishment of the office of the Commissioner for the Extinguishment of Native Title (Temm 1990: 19). Māori became disenfranchised in their own land, which has resulted in many Māori grievances. "The Treaty is the shared touchstone and starting point of "official" Maori/Pakeha interaction. Its place in the New Zealand scheme of things, like the place of the Maori community, has been largely defined by the Pakeha' (Jackson 1988: 168).

Following its signing, the Treaty was largely regarded by Pākehā as being null and void and was dismissed as irrelevant. In 1877, during the case of Wi Parata $v$ The Bishop of Wellington, Chief Justice Prendergast ruled that the Treaty was 'a simple nullity' (Temm 1990: 24). This judgement was unfathomable to Māori. 'The law's eventual dismissal of the 
Treaty confirmed the Maori sense of betrayal' (Jackson 1988: 48).

Under Article Two of Te Tiriti o Waitangi, Māori were guaranteed tino rangatiratanga over their taonga or treasured possessions (Kawharu 1989: 317). According to a Māori worldview, the meaning of the word taonga is not restricted to the tangible. The meaning of taonga extends further to encompass the intangible, such as language and 'all those things to do with pedagogy and epistemology - what counts as knowledge, how that knowledge is to be preserved, transmitted and evaluated' (Glynn 1998: 4). Therefore, Article Two guarantees Māori full Chieftainship over their knowledge including te reo Mãori. 'The second article is the most far-reaching. It assures Maori New Zealanders that the Crown will protect all their cultural and property rights - and this is no mere protection; it is an explicit guarantee of those rights' (Temm 1990: 18).

In Article Three of Te Tiriti o Waitangi, the Queen of England promises to protect Māori and guarantees they will have the same rights and privileges of her British subjects (Kawharu 1989: 318). British subjects in New Zealand had the right to be educated in their own language, and the privilege of having the curriculum of mainstream education tailored to their specific cultural needs. Therefore, under the third article of Te Tiriti o Waitangi, Māori should have been provided with a pedagogy that was tailored to their specific cultural needs, including being taught in their own language.

To this day, Te Tiriti o Waitangi has not been honoured. In fact, immediately after this pact was signed, it was intentionally dishonoured through the Pākehā policy of assimilation. Assimilation can be defined as becoming absorbed and incorporated into another culture (Soanes et al 2001: 46). In this case, it was intended that Māori would become absorbed by Pākehā culture, and would have to adjust to this change. This policy of assimilation was especially evident within the State education system. As a result of this 
policy, Aotearoa/New Zealand has witnessed the near death of te reo Māori. Māori have been victims of

...the cultural deprivation and denigration that has denied positive knowledge of, and close links to, their own cultural heritage. The fact that the law, the education system, and other bases of power in New Zealand have been subject to Pakeha control, has meant that Maori socio-cultural status has been defined by monocultural processes unwilling or unable to adequately serve different cultural needs (Jackson 1988: 173).

\section{Mission schools}

Eurocentric education started in New Zealand on 12 August 1816 with the opening of the first mission school by Thomas Kendall of the Church Missionary Society (Anglican) at Rangihoua, in the Bay of Islands (Ka'ai-Oldman 1988: 22; Barrington \& Beaglehole 1974: 10). By 1830, there were many mission schools throughout Northland that taught subjects such as reading, writing and arithmetic, as well as catechism (Ka'ai-Oldman 1988: 22; Walker 1990: 146). The general Pākehā belief was that Māori were 'most anxious for civilization' (Hawtrey 1840: 10).

Mission Schools were set up to civilize and convert Maori people to what was promoted as a superior, more enlightened view of the world. Incorporated in this process was the devaluing and marginalizing of the worth and legitimacy of a Maori world view (Merritt 1996: 82).

According to Ka'ai-Oldman, 'the missionaries saw themselves as the instrument by which the Maori people would be brought from the state of barbarism to civilised life' (Ka'ai-Oldman 1988: 22). This school of thought was typical of the time and equates civilisation with Christianity (Cesaire 1972: 11). These mission schools could be referred to as the tools of cultural invaders. Cultural invasion occurs when the 
'invaders' force their own world-view onto another group, such as the missionaries in these schools influencing Māori children (Darder 1991: 36). Missionaries sought to interrupt the intergenerational transmission of language and culture, thereby invalidating the world-view of Māori and paving the way for their own world-view to replace that of Māori.

In a general sense, ideas of monoculturalism assumed that Pakeha values and ways of doing things were the only valid ones, and that other cultures should accept those ways either because they did not possess appropriate methods of social order themselves, or because they possessed ideals which were inferior. The basis of those assumptions was an innate prejudice against the norms of other cultures. Their implementation in policies exercised through political power and ethnically-defined "right" of civilised superiority or competence led to personal and structural racism (Jackson 1988: 49).

The mission schools did not attempt to accommodate the cultural need of Māori children. In fact these schools assisted significantly in the formation of Māori as a subordinate culture in society, through casting Māori children as the subordinate culture of the education system. The subordinate culture refers to the culture that lives in 'social and material subordination to the dominant culture' (Darder 1991: 30). Māori children had their educational environment dictated to them by the dominant culture. The dominant culture refers to the culture that is in control of the material and symbolic wealth in society' (Darder 1991: 30).

At this time the Māori children within the mission schools were taught in their own language, and Aotearoa/New Zealand's population became more literate than that of the United Kingdom. However, this literacy was in Māori, not English (Bell 1991: 67). Unfortunately, the use of te reo Māori as the medium of instruction was to be short lived. 


\section{Education Ordinance 1847}

In 1847, the Education Ordinance was introduced in order to aid the assimilation process (Walker 1990, p.146). Sir George Grey introduced the Education Ordinance, as he believed that it would speed up the process of assimilation by insisting that English be the medium of instruction in schools. "To Grey it appeared essential, for reasons that were to him so obvious as not to need repeating, that all the children should be brought up to speak and read the English language' (Barrington \& Beaglehole 1974: 44).

The Education Ordinance also encouraged the establishment of more boarding schools, particularly industrial training boarding schools, as they would 'take the children away from the 'demoralising influences of their villages', thereby 'speedily assimilating the Maori to the habits and usages of the European" (Walker 1990, p.46). This is a form of cultural violence. Cultural violence occurs when a society is forcibly removed and separated from their roots, their land, their language and their traditions.

The Ordinance resulted in the establishment of new Church Boarding Schools between the years of 1848 and 1852 (Barrington \& Beaglehole 1974: 45-50). These schools separated Māori children from their whānau, therefore separating them from their language and cultural base and increasing the chance of language loss and assimilation. Furthermore, under the Education Ordinance Act, mission schools were to be subsidised with public funds, perhaps as an incentive to carry out the Government's aims (Walker 1990: 146).

The Education Ordinance was the first formal move towards language domination and hegemony. Language domination occurs when members of the dominant culture silence an Indigenous language. This often takes place in the classroom, when the dominant language is viewed as superior to the Indigenous language as a result of the values and beliefs instilled in the school system (Darder 1991: 36). Hegemony 
works in much the same way, by making the subordinate culture believe in the authority of the dominant culture through the power that the dominant culture wields in social systems and institutions (such as the education system) (Darder 1991: 34). According to Giroux, 'Hegemony refers to a form of ideological control in which dominant beliefs, values, and social practices are produced and distributed throughout a whole range of institutions such as schools, the family, mass media and trade unions' (cited in Darder 1991: 33-34). Therefore, the culture and values of the oppressor are promoted over that of the oppressed, whose culture and values are devalued through the colonising powers.

Although legislation such as the 1847 Education Ordinance was common practice at the time, today it is seen as a policy that was in violation of the rights of Indigenous peoples, as outlined by the World Council of Indigenous Peoples in the Declaration of Principles of Indigenous Rights. Principle 14 of this Declaration states that Indigenous peoples have the right to receive education in their own language' (cited in Anaya 1996: 189). Clearly this right was not afforded to Māori.

By the 1850s the European settler population exceeded that of Māori and the decline in Māori numbers was compounded by deaths from introduced diseases and from the Land Wars (between certain iwi and the Crown) of the 1860s (Moorfield 2006: 109). The land wars were also responsible for the closure of many mission schools and subsequently, the end of the missionary period in Aotearoa/New Zealand. 'War closed the schools, and their closing can be taken to symbolize the break in relations which had occurred between the two races' (Barrington \& Beaglehole 1974: 95).

This 'break in relations' is obvious in the following quote by Sherborne Rimpton from the introduction to the book Justice To New Zealand, Honour To England which was published in 1861: 'The fairest of England's colonies is 
threatened with disaster. There is a general cry that to save the colony we must exterminate the natives' (Hawtrey 1861: 3).

\section{Native Schools Act 1867}

The 1867 Report to the Minister of Native Affairs concerning Native schools found that these mission schools put too much emphasis on religion and were not furthering the Government's objectives of removing Māori from their community-based living and encouraging the use of the English language (Walker 1990: 146). Furthermore, the Report concluded that the Government should intervene so as to regulate the curriculum and place the emphasis on the English language (Walker 1990: 147).

The curriculum was a colonial tool used to aid in the reproduction of the dominant world-view. According to Darder, 'Curriculum traditionally refers to the coursework offered or required by an educational institution for the successful completion of a degree or credentialing objective' (Darder 1991: 19). However, the curriculum is composed of knowledge that is seen as important by the group that designs the curriculum. Generally speaking, the group that has the power to decide the curriculum is drawn from the dominant culture in society (Darder 1991: 19). Therefore, the curriculum reflects the values of this dominant culture, while neglecting the needs of the subordinate cultures.

As a result of the Report to the Minister of Native Affairs, the 1867 Native Schools Act was introduced in order to establish Native schools under the administration of the Government and in doing so, provide the Government with more control over the content of the curriculum (Walker 1990: 147). Essentially, this Act replaced mission schools by establishing Native schools for Māori children. The settler Government was to claim part responsibility for the provision of teachers and school buildings, provided that Māori gifted land for the school to be built and covered the remaining costs for teachers, buildings and books. In 1871, this Act was 
amended so as to remove the financial burden from Māori, which had been proving too heavy (Barrington \& Beaglehole 1974: 101, 105-106). By 1874, this amendment had resulted in twenty-five new schools, increasing from thirteen in 1870 to thirty-eight in 1874 (Ka'ai date unknown: unpublished paper).

By the late 1870s, many Māori petitioned in favour of European knowledge, as there was a widespread perception that this knowledge was responsible for the perceived 'success' of Pākehā economically and the key to a higher standard of living (Ka'ai date unknown: unpublished paper; McCarthy 1997: 33). Therefore, some Māori leaders of the time accepted the policy of ignoring te reo Mãori due to the belief that there was no other means for the advancement of Māori people and that Pākehā knowledge would further Māori children (Ka'aiOldman 1988: 24). In 1876, there was a petition by Māori leaders to amend the Native Schools Act so that 'there should not be a word of Maori allowed to be spoken in the school' (Bell 1991: 67). This is disturbing as it meant that the colonised were active participants in the further colonisation of their people based on the understanding that the coloniser was a model of success (Freire 1972b: 22).

\section{The Native Schools Code 1880}

The Native Schools Code of 1880 outlined the expectation that teachers have a knowledge of te reo Mãori, but only in the context of teaching English to the junior classes (Walker 1990: 147). Therefore, the Native Schools Code 1880 aided the process of assimilation by placing restrictions on te reo Māori in schools (Ka'ai-Oldman 1988: 23). Ka'ai refers to the Code as 'utterly patronising and racist' (Ka'ai date unknown: unpublished paper).

Racism can be seen throughout the history of New Zealand's State education system and is a reoccurring theme in the education of Māori children. Racism can be defined as the belief in superiority of a particular race, and antagonism 
and prejudice towards members of a different race based on this idea of superiority (Soanes et al 2001: 731). According to Darder, there is a distinction between individual racism and institutional racism. For example, a Pākehā person acting against Māori can be classed as individual racism, and the collective acts of the Pākehā community against the Māori community can be classed as institutional racism (adapted from Darder 1991: 40). The legislation and regulation of the State education system, such as the 1880 Native Schools Code, is an example of institutional racism against Māori. When discussing the two forms of racism Darder notes: 'what is most significant is that both forms of racism result from deep-rooted prejudices and stereotypes' (Darder 1991: 41).

In 1894, the School Attendance Act was introduced, making attendance at school compulsory. Pākehā children were legally required to attend school between the ages of seven and thirteen. However, it was only compulsory for Māori children to attend school up to the end of Standard Four (approximately age 10). This was also a form of institutional racism as the State had different educational assumptions and expectations for Māori. Furthermore, there were strict regulations placed on the reasons why children might not be able to attend school, and these did not include tangihanga or hui (Ka'ai date unknown: unpublished paper). Clearly, this Act was not culturally sensitive or culturally tailored to Māori, as was promised under Article Three of Te Tiriti o Waitangi.

In 1897, the Revised Native Schools Code was introduced (Walker 1990: 147). This regulation continued to allow te reo Māori to be spoken in junior classes for the purpose of teaching English. However, it was argued that the use of te reo Mãori should be discontinued as soon as possible and that English should become the sole language in the classroom (Barrington \& Beaglehole 1974: 144).

The State education system legislation and regulation at his time collectively aided the assimilation process by stripping 
Māori children of their cultural base through a process of language and cultural domination (Walker 1990: 147). Furthermore, it was in breach of the Treaty that Māori and Pākehā signed at Waitangi in 1840 and reflects a common colonial world-view that denied the rights of Indigenous peoples. A century on, it can be seen as directly violating our current understanding of Indigenous rights. Article 8 of the United Nations Declaration on the Rights of Indigenous Peoples ${ }^{2}$ states:

1. Indigenous peoples and individuals have the right not to be subjected to forced assimilation or destruction of their culture.

2. States shall provide effective mechanisms for prevention of, and redress for:

a. Any action which has the aim or effect of depriving them of their integrity as distinct peoples, or of their cultural values or ethnic identities;

b. Any action which has the aim or effect of dispossessing them of their lands, territories or resources;

c. Any form of forced population transfer which has the aim or effect of violating or undermining any of their rights;

2 The Declaration on the Rights of Indigenous Peoples was adopted by the General Assembly of the United Nations on 13 September 2007. 143 countries voted in favour of the charter which outlines the rights of the world's estimated 370 million indigenous people. New Zealand was one of four countries (along with the United States of America, Canada, and Australia) that voted against the Declaration and refused to support it. This was a move indicative of the way in which those nations view the rights of their native peoples. Australia has since gone back on its initial decision and endorsed the Declaration on 3 April 2009. Fortunately, New Zealand has also reversed its initial decision and endorsed the Declaration on 4 April 2010. 


\author{
d. Any form of forced assimilation or \\ integration; \\ e. Any form of propaganda designed to \\ promote or incite racial or ethnic \\ discrimination directed against them. \\ (United Nations date unknown: electronic source)
}

Therefore, all of the legislation that supported the assimilation of Māori children by way of the State education system is considered illicit under current international regulations.

\title{
Te reo Mãori banned
}

By 1903, the use of Māori as a medium of instruction and communication within schools was officially discouraged by educational authorities (Bell 1991: 67). Then in 1905, teachers in Native Schools were strongly advised by the Inspector of Native Schools to encourage Māori children to speak only English in the playground (Walker 1990: 147). This led to widespread prohibition and eventually children in Native Schools were forbidden to speak te reo Mãori in the classroom or in the playground and in many cases corporal punishment was used freely as an oppressive tool against children who disobeyed (Ka'ai-Oldman 1988: 23). According to Walker, 'The damaging aspect of this practice lay not in corporal punishment per se, but in the psychological effect on an individual's sense of identity and personal worth' (Walker 1990: 147). The child's native language is the primary form of expression of that child's thoughts and feelings. Therefore, language provides empowerment for a child.

Language is the life line and sustenance of a culture. It provides the tentacles that can enable a child to link up with everything in his or her world. It is one of the most important forms of empowerment that a child can have. Language is not 
only a form of communication but it helps transmit the values and beliefs of a people (Pere 1997: 9).

Therefore, according to Darder, suppressing this language is a form of 'psychological violence' (Darder 1991: 37-38). McCarthy illustrates the psychological effect of this prohibition: 'Native Māori speakers who were graduates of the 1900s schooling era have in the majority of cases deliberately not taught their children to speak Māori. Responses of this kind are directly linked to the belief, firmly inculcated, that to speak Māori was of no practical use' (McCarthy 1997: 33). Effectively, if speakers of te reo Māori did not have positive attitudes towards their native tongue, they were reluctant to transmit their knowledge to new generations regardless of how proficient their language skills were. Moreover, many Māori who had been physically punished for speaking te reo Mãori during their schooling were subsequently reluctant to submit their own children to this experience, and therefore chose to speak English only to their children.

This policy of prohibition was usually accompanied by negative 'teacher expectations' or negative attitudes of teachers towards all things Māori, including the language. Teacher expectations are the assumptions and judgements made about children by their teachers either consciously or unconsciously (Darder 1991: 19). That is, how the children and their ability are perceived by the teacher. For the most part, this involves making judgements about student's educational potential. The expectations that teachers have of students are often based on racial stereotypes. Darder states that teachers are more likely to hold negative expectations for lower-class and bicultural children than for middle class white children' (Darder 1991: 17). Teachers anticipate differences in levels of achievement, this in turn impacts on how they allocate their time, which students they invest in, and how the students feel about their learning environment. Essentially, teachers expect less of students from certain backgrounds and these students will often fulfill that prophesy. 
The negative attitudes of teachers towards Māori children and their language impacted on the children's sense of self worth, and usually, they reinforce the hegemonic belief that Māori are in fact academically inferior. The exclusion of the Maori language from the primary school curriculum coupled with the negative attitude of many teachers towards the language, negatively affected the attitude of Maori people themselves towards their own language' (Ka'ai-Oldman 1988: 23). Furthermore, the belittlement of the Māori language has also impacted negatively on Māori self-esteem. Māori felt whakama $\bar{a}^{3}$ of te reo Māori due to the Pākehā notion that the English language was superior. According to McCarthy, Through both overt and covert processes the colonized are inculcated with the belief that their culture and all that it offers is inferior to that offered by the colonising culture' (McCarthy 1997: 32).

In 1910, the Annual Report from the Minister of Education Regarding Native Schools was released. The 'Teachers at Native Schools' section of this Report found that of approximately 100 schools, only three of these had Māori Head Teachers, all of whom were male. Furthermore, the Report found that there were female Māori teachers, but they held the position of 'Junior Assistants' and therefore, were on low-wages. This is yet another example of racism and cultural domination in that the State restricted the advancement of Māori people by rarely allowing them to occupy leadership positions in the Schools (Ka'ai date unknown: unpublished paper).

In 1925, the Advisory Committee on African Education, which was set up by the British Colonial Secretary, found that 'education should be adapted to the traditions and mentality of the people and should aim at improving and conserving what was best in their institutions' (Ka'ai-Oldman 1988: 23; Barrington \& Beaglehole 1974: 202). This finding impacted on the education policy of New Zealand, and from 1931, aspects

3 Embarrassed, ashamed 
of 'Māoritanga' were incorporated into the curriculum of some schools. However, this was minor and somewhat cosmetic as only cultural content was added. Māori language was again not included (Ka'ai-Oldman 1988: 23). In 1930, the New Zealand Federation of Teachers endeavoured to have the Māori language introduced as part of the curriculum. Unfortunately, this attempt was shut down by the Director of Education at the time, T. B. Strong, who was of the view that the natural abandonment of the native tongue involves no loss to the Māori' (Ka'ai-Oldman 1988: 24; Moorfield 2006: 109). It can be argued that this attitude politically fuelled the continued opposition by the dominant Pākehā culture toward the Māori language.

Initially, some Māori leaders, such as Apirana Ngata, believed that young Māori would have sufficient levels of te reo Mãori at home, and so, did not require the language to be a part of the school culture (Barrington \& Beaglehole 1974: 242). However, Ngata quickly realised that this was a mistake. In 1939, whilst speaking at a conference of young Māori leaders in Auckland, Ngata explained that he had previously opposed the teaching of te reo Mãori in Native schools because he had thought that there was not enough time for students to learn both languages, Māori and English. He then explained that he had come to the realisation that 'nothing was worse than for one to be with Maori features but without his own language' (cited in Barrington \& Beaglehole 1974: 207).

Before the Second World War the majority of the Māori population were native speakers of te reo. Following the Second World War, the inter-generational transmission of te reo Mãori changed dramatically. This was primarily a result of massive social, political and economic changes within Māori society at that time. From the 1950s there was a migration of Māori to the urban centres seeking employment. The steady urban drift led to the disintegration of rural te reo Māori speaking communities (Benton 1981: 16-17). 
In addition, at the time there was a policy of 'integrating' urban Māori into the wider population, also known as 'pepperpotting'. Essentially, this meant that Māori families were placed in predominantly Pākehā suburbs, with the hope that they would 'integrate' into society. This policy was created to prevent the development of urban Māori communities and had the follow on effect of preventing the formation of te reo Māori speaking groups because Māori speakers were physically isolated from other Māori speakers. Therefore, English was firmly established as the language of not only the workplace, but also of the local neighbourhood and soon became the primary language through which daily social interactions were undertaken (Te Taura Whiri i te Reo Māori date unknown: electronic source).

This policy had far-reaching repercussions, of which the most severe was that, for the first time, Māori children were being raised as monolingual speakers of English. This new phenomenon was intensified by the high percentage of Māori under the age of 20 at that time. These conditions led to a rapid language shift among the Māori population, especially among the first generations of Māori who were born and raised in the city. However, it should be noted that the use of English in communication with children, does not mean that urban Māori households were exclusively English language domains. Māori parents and adults living in the household would often speak Māori to one another. Therefore, the children would usually develop passive heritage language skills as a result of hearing te reo Mãori spoken (Benton 1981: 16-17).

\section{The Hunn Report 1960}

In 1960, after many years of assimilation, cultural invasion, cultural subordination, language domination, hegemony, racism and negative teacher expectations, the Hunn Report was released. Named after the Head of the Department of Māori Affairs, J. K. Hunn, it found that there was a huge 
disparity between the educational achievement of Māori and that of Pākehā. The Report found that while 3.78\% of Pākehā children reached the Sixth Form, only $0.5 \%$ of Māori children did so. The Report therefore advocated 'integration' over 'assimilation'. Hunn's interpretation of the word 'integration' implied that both parties should consent to integrating, and that both should have input into what this would entail. However, this interpretation was effectively ignored by the State education system. According to Ka'ai, 'The reality was more like the kahawai and the shark analogy "Let's integrate", said the shark to the kahawai. "Have I any choice?" he replied' (Ka'ai-Oldman 1988: 24).

The Hunn Report was significant in that it proposed a society which should embrace and respect Māori as a minority group in Aotearoa/New Zealand. Impressive as this sounds, Hunn's vision for a pluralistic society never came to fruition as people involved in State education across the country were resistant to changing their attitudes (Ka'ai-Oldman 1988: 24). This is to be expected as the State education system had been founded on hegemonic ideas and practices for 140 years and had shaped the attitudes of teachers and administrators.

Some recognition of biculturalism within the classroom emerged by the late 1960s. In 1967, the Report on Maori Education was released by the New Zealand Educational Institute. This Report recognised the value of biculturalism, stating that, 'It must be remembered that the Maori is both a New Zealander and Maori. He has an inalienable right to be both, and to be consciously both, and he is likely to be a better citizen for being both (cited in Ka'ai-Oldman 1988: 25). Then in 1971, the National Advisory Committee on Maori Education Report pushed the concept of biculturalism in the classroom. This Report, along with pressure from the Māori community, resulted in some positive changes for Māori within the State education system. By 1973 there were Māori Studies courses established in all seven teachers colleges around the country. More importantly, in 1974 the Department of Education 
created six new posts for Māori Education Advisers (Ka'aiOldman 1988: 25-26).

The minor recognition of te reo Mãori in secondary schools and universities was a positive step. However, it did little in the way of compensating for the damage previously inflicted upon the health of the language. Despite the advancements, te reo Mãori continued to suffer. According to Glynn, 'Participation in mainstream education has come for Māori at a cost of their own language, culture and identity' (Glynn 1998: 4). This is evident when one considers the statistics.

\section{Te reo Māori statistics}

In 1900, over ninety per cent of Māori children started school with te reo Māori as their first language. However, by 1960 this had fallen to twenty-five per cent (Ka'ai-Oldman 1988: 24). The perception of te reo Māori as a language of little value or benefit to the Māori people had evolved through the colonial era and become inherent in the popular culture of mainstream New Zealand' (O'Regan 2006: 158). This was compounded by the impact of rapid Māori urbanisation and the aftershock of the Second World War. By 1979, the loss of the Māori language was so great that it was believed that it would become extinct if nothing was done to save it (Walker 1990: 147-8).

By the mid-1970s, the Māori language was in great danger of becoming extinct as a medium of everyday communication. Fluency was restricted to a small number of speakers, many of them middle-aged and older, who resided largely in rural areas. Fluent Māori speakers were outnumbered four to one by predominantly English-speaking people of Māori descent. The conclusion was obvious - the viability of the Māori language as a language of daily communication was in serious doubt. Drastic measures were needed to ensure its survival (Moorfield 2006: 109).

According to Ka'ai-Oldman, by 1984 the number of children entering primary school with Māori as their first language was most likely less than two per cent (Ka'ai-Oldman 
1988: 24). Further evidence of the success of colonial tools, such as language domination, can be found in the fact that New Zealand is among the most monolingual countries in the world. It is estimated that ninety to ninety-five per cent of New Zealanders can not speak any other language apart from English (Bell 1991: 66). This percentage is a lot greater than other primarily English speaking nations such as Britain, the United States of America, Canada, and Australia (Bell 1991: 66).

Te reo Māori is considered to be the core of Māori culture, as illustrated in the following Māori proverb:

Ko te reo te mauri o te mana Maori

The language is the very life principle of Maori Mana (Jenkins \& Ka'ai 1994: 163).

The belief among Māori is that the language is the key to a deeper understanding of the culture and their world-view and values' (Moorfield 2006: 108). The language you speak affects your thoughts and experience. The Sapir-Whorf hypothesis makes the claim that the structure of the language one habitually uses influences the manner in which one thinks and behaves' (Kramsch 1998: 11). The hypothesis is that language affects the way in which we view the world and the way speakers of different languages think and behave differently because of it. Therefore, te reo Māori is a marker of Māori identity and is crucial to an understanding of Māori world-view.

The New Zealand State education system has failed Māori communities and their children. It was a major contributor to the rapid loss of Māori language. Furthermore, New Zealand State schools have been locked into the cycle of social and cultural reproduction of the dominant Pākehā culture based on the presumption that Pākehā culture is the most appropriate for all of Aotearoa/New Zealand's peoples. Obviously this presumption was incorrect, as this cycle has 
led to the decline in the educational achievement of Māori children and, more importantly, the gradual deterioration of te reo Māori.

Since the signing of the Treaty of Waitangi in 1840, and up to the later part of the twentieth century, the dominant European population thought that once Māori were shown the superiority of the European way, they would reject their own language and culture, and adopt that of the dominant society. Instead, Māori have rejected assimilation; but despite this rejection, the battle to preserve the language has been arduous (Moorfield 2006: 108).

In both direct and indirect ways, the legislation passed regarding the establishment and evolution of the New Zealand education system has created amongst many Māori families one of the greatest, if not the greatest injustice of them all the inability to speak one's own native tongue.

\section{Kaupapa Māori education}

Indigenous people have the right to all levels and forms of education. They also have the right to establish and control their educational systems and institutions, providing education in their own language (Article 14, Coolangatta Statement 1993 cited in Glynn 1998: 4).

The State education system failed many Māori children. After many years of being affected by cultural subordination and language domination, and with no indication of positive action by the State, Māori families and communities took matters into their own hands. That is, Māori decided to start reversing the cycle of language decline within their society by immersing their children in a bilingual environment.

Most people who are changing their way of life, tend to be enthusiastic in the first instance about the new culture. But after a while, and sometimes it's quite a long while, perhaps as much as a century, people begin to feel that western culture is such a big hungry thing that they feel lost in it and they begin 
to emphasise that they possess things of their own which are not part of the way of life of all the rest of the world. Some people feel this need for cultural identity sooner than others (Biggs 1977: 8).

Kaupapa Māori schooling is an example of resistance. According to Darder, 'This is most apparent when oppositional ideologies of subordinate cultures attempt to resist and challenge the dominant ideologies in an effort to break through the existing relations of power' (Darder 1991: 42-43). Kaupapa Māori schooling can be described as a critical Māori pedagogy, and was the positive way in which Māori educational professionals responded to the assimilation process and subsequent language loss (Glynn 1998: 5). Kaupapa Māori schooling, such as Te Kōhanga Reo, Te Kura Kaupapa Māori, and Te Wharekura has been the key in breaking the cycle of social and cultural reproduction of the dominant Pākehā culture that has been identified within the State education system. The curriculum is compiled through a selection process of which knowledge is appropriate to teach the children. If the curriculum is chosen to meet the child's cultural needs, the child has a head start. If not, the child is on the back foot. Teachers and schools need to be responsive to the educational needs of their students if they have any hope of engaging children positively in learning.

Te Kōhanga Reo initiated a programme that totally immersed pre-school Māori children in the values, traditions, customs and stories of traditional Māori. 'For the first time in over two generations, Māori preschoolers were receiving the language, cultural knowledge and life principles that would help them make better sense of their own cultural worldview' (Glynn et al. 2006: 53).

\section{Te Kōhanga Reo}

The idea of Te Kōhanga Reo was first discussed at the 1981 Hui Whakatauira (Ka'ai-Oldman 1988: 27). The Te Kōhanga 
Reo movement was a result of Māori communities working together with the Māori Affairs Department to arrest the rapid decline of te reo Maori, hence the Te Kōhanga Reo imperative:

Me korero Maori i nga wa katoa, inga wahi katoa

Speak Maori at all times and in places (Jenkins \& Ka'ai 1994: 163)

The aim was to have every child who was enrolled in Te Kōhanga Reo bilingual by the age of five (Walker 1990: 238). On a day to day basis, the Te Kōhanga Reo were to be operated by kuia ${ }^{4}$ and koroua ${ }^{5}$ who were native speakers of te reo Māori (Walker 1990: 238).

A critical point to make is that Te Kōhanga Reo was not initiated or funded by the Department of Education from the outset. Yet it is very much an educational strategy to correct the huge underachievement of Māori children stemming from Pākehā hegemonic practices in education over the previous 140 years. In fact, Te Kōhanga Reo originally came under the mantle of the Department of Māori Affairs. Each new Te Kōhanga Reo was granted $\$ 5000$ as an establishment grant from the Department of Māori Affairs. However, the whānau were required to cover the ongoing operational costs (Walker 1990: 238). The lack of support by the State for Kaupapa Māori schooling has since been condemned by the Convention (No.169) Concerning Indigenous and Tribal Peoples in Independent Countries. Article 27 of the Convention states, 'Governments shall recognise the right of these peoples to establish their own educational institutions and facilities...Appropriate resources shall be provided for this purpose' (cited in Anaya 1996: 201).

The first Te Kōhanga Reo was established in April 1982 at Pukeatua Kōkiri Centre, Wainuiomata (Jenkins \& Ka'ai 1994: 167). Despite the cost to parents, the Te Kōhanga Reo

Elderly women

5 Elderly men 
movement experienced a huge influx. In November 1983, there were 188 Te Kōhanga Reo around the country (Walker 1990: 239). By June 1990, this number had rapidly increased to 609 (Jenkins \& Ka'ai 1994: 168). Each of these Māori focused early childhood centres catered specifically to the needs of Māori children by delivering a curriculum established by Māori parents and Māori educational professionals for Māori children. According to Ka'ai-Oldman, 'Te Kōhanga Reo is one of the most dynamic and innovative educational programmes in the country' (Ka'ai-Oldman 1988: 27). The existence of an alternative Māori school system was obviously a critique on the conventional state system and the rapid growth of the school system is testimony to the fact that they fulfill a need for Māori, providing the tools of transformation, liberation and emancipation.

\section{Te Kura Kaupapa Māori}

Following the success of Te Kōhanga Reo, Māori parents became concerned about where to place their school-age children who were fluent speakers of te reo Mãori. Children leaving Te Kōhanga Reo and entering mainstream English language state education quickly lost their Māori language proficiency. At that time there were only twelve bilingual schools throughout the whole country that offered some instruction in the Māori language. Furthermore, Māori parents did not like the idea of sending their children to State schools, as the success of the Te Kōhanga Reo movement was attributed to community control (Walker 1990: 239).

These concerns were raised at the Māori Educational Development Conference in 1984 (Walker 1990: 239). Of those who attended, 300 were Māori language teachers. These teachers expressed their belief that the State education system was 'inherently flawed' and that it was actually 'manufacturing Maori failure' (Walker 1990: 242).

Although the Maori community has never forfeited its mana or denied its cultural uniqueness, the policies of 
monoculturalism continually place it under stress. The reality of racial prejudice and the demeaning of Maori identity create a sense of cultural deprivation as real as that engendered by the stresses of economic deprivation (Jackson 1988: 72).

Therefore, it was decided that a school system be developed consistent with the Te Kōhanga Reo philosophy of language revival, recovery and maintenance. The Māori primary school system, called Te Kura Kaupapa Māori, and the secondary schools, called Te Wharekura, have evolved from the principles of Te Kōhanga Reo, so as to provide excellence in Māori language, knowledge and cultural frameworks. The first Kura Kaupapa Māori was established at Hoani Waititi Marae in 1985 (Jenkins \& Ka'ai 1994: 172). It was set up in order to 'find placements for the emerging 'graduates' from Te Kohanga Reo, the first of whom had tried State schools and soon found the programmes alienating' (Jenkins \& Ka'ai 1994: 172).

Many of the parents, because they have experienced language and cultural loss, are eager to get their children back to learning the language. The key in these schools has been to tap into that intense emotional energy for language and cultural revitalization so that it coincides with learning intervention (Smith 2000: 222).

Kaupapa Māori education has validated the merit of a Māori pedagogy. Kaupapa Māori education is a statement of Māori people reclaiming power as they were no longer willing to participate in the cultural reproduction of mainstream education in Aotearoa/New Zealand (Ka'ai 1995: 39).

\section{The future of Te reo Mãori and education}

It is an indictment on the State to have designed a strategy of assimilation advanced by educators in schools to accelerate the decline of the Māori language and culture and the absorption of Māori into Pākehā society. For this cycle to cease, it is critical that educators recognise the role language 
plays as one of the most powerful transmitters of culture; as such it is crucial to the survival of a cultural community (Darder 1991: 37).

'Māori people constitute about 15 percent of a total New Zealand population of about 4 million. We are about 20 percent of the school-aged population. We are very young, and our population is growing' (Smith 2000: 220). Therefore, Māori language and culture remain extremely vulnerable.

The State needs to be more proactive and responsive in its support of Kaupapa Māori educational institutions. According to Jackson, there is 'a very real challenge confronting Pakeha society and its institutions, as well as the Maori community, to ensure that the transmission of Maori language, values and cultural ideals is promoted' (Jackson 1988: 174). Furthermore, it is now time for the State to take more responsibility in 'cleaning up the mess' that they have created for Māori within the State education system for the last 170 years. 'It is important that we take heed of our past, for it is from this template that the reconstruction of a better future is shaped' (McCarthy 1997: 30).

The State has an obligation to right the wrongs of the past and uphold the promises set forth in Te Tiriti o Waitangi. One such promise was in Article Two, where Māori were guaranteed protection of all taonga. The Te Reo Māori claim was submitted to the Waitangi Tribunal in 1985 by Ngā Kaiwhakapumau i Te Reo Māori. The claim was based on the assertion that te reo Mãori is a taonga that should have been protected by the Crown under Article II of the Te Tiriti o Waitangi. Tâ Hēmi Henare (Sir James Henare), one of the nation's most cherished kaumātua, made the following statement whilst giving evidence in 1986 for the Waitangi Tribunal Claim ${ }^{6}$ relating to the Māori language:

If the language dies as some predict, what do we have left to us? Then, I ask our own people who are we?

6 This is commonly known as the WAI11 claim 
'Language', according to Oliver Wendell Holmes, 'is a solemn thing, it grows out of life, out of its agonies and its ecstasies, its wants and its weariness. Every language is a temple in which the soul of those who speak it is enshrined.' Therefore, the taonga, our Māori language, as far as our people are concerned, is the very soul of the Māori people. What does it profit a man to gain the whole world but suffer the loss of his own soul? What profit to the Māori if we lose our language and lose our soul? Even if we gain the world. To be mono-lingual, a Japanese once said, is to know only one universe... (Waikerepuru and Nga Kaiwhakapumau I Te Reo Incorporated Society, cited in Ka'ai et al. 2004: 202).

In the Report of the Waitangi Tribunal on the Te Reo Māori Claim (WAI 11) 1986, the Waitangi Tribunal asserted that te reo Mãori was included in the description of taonga (Ka'ai date unknown: unpublished paper). Therefore, the State is obligated to protect te reo Māori under this Charter. In addition, the Waitangi Tribunal, in the summary of the Orakei Report 1987, stated that Te Tiriti o Waitangi was not intended merely to fossilise the status quo but to provide a direction for future growth and development. It is not intended as a finite contract but it is the foundation for a developing social contract' (cited in Glynn 1998: 3).

This statement suggests that the State should be more open to providing and supporting a critical Māori pedagogy, such as Kaupapa Māori schooling, as a foundation to educate Māori more effectively within the State education system. Currently, 'Maori educational aspirations, Maori-preferred approaches to learning and teaching, and Maori perspectives on educational research are barely visible within mainstream New Zealand education' (Glynn 1998: 4). This has caused many Māori students to feel alienated, as often there are significant cultural differences between Māori children and the Pākehā teachers who teach them. It is the responsibility of the State to make provisions for appropriate teacher training and 
to ensure that teaching graduates do not hold deeply entrenched negative attitudes towards Māori, and are capable of educating children of all cultures (Ka'ai-Oldman 1988: 26). Ideally, all graduating teachers should be bilingual, as only then can they truly meet the needs of Māori children. 


\section{References}

Anaya, S. J. (1996). Indigenous Peoples in International Law. New York: Oxford University Press.

Barrington, J. M. \& Beaglehole, T. H. (1974). Maori Schools in a Changing Society: An Historical Review. Wellington: New Zealand Council for Educational Review.

Bell, A. (1991). The Politics of English in New Zealand. In G. McGregor \& M. Williams (Eds.), Dirty Silence: Aspects of Language and Literature in New Zealand, (pp. 65-75). University of Waikato Winter Lecture Series of 1990. Auckland: Oxford University Press.

Benton, R. A. (1981). The Flight of the Amokura: Oceanic Languages and Formal Education in the South Pacific. Wellington: New Zealand Council for Educational Research.

Benton, R. (1991). The History and Development of the Māori Language. In G. McGregor \& M. Williams (Eds.), Dirty Silence: Aspects of Language and Literature in New Zealand, (pp. 1-18). University of Waikato Winter Lecture Series of 1990. Auckland: Oxford University Press.

Biggs, B. (1977). What is Oral Tradition. In S. Vatu (Ed.), $\mathrm{Na}$ Veitalanoa Me Baleta Na I Tukutuku Maroroi - Talking About Oral Traditions, (pp. 1-12). Suva: Fiji Museum.

Cesaire, A. (1972). Discourse on Colonialism. New York: Monthly Review Press.

Darder, A. (1991). Culture and Power in the Classroom: A Critical Foundation for Bicultural Education. Westport, Connecticut: Bergin \& Garvey.

Freire, P. (1972). Pedagogy of the Oppressed. Harmondsworth, Middlesex: Penguin Books Ltd.

Glynn, T. (1998). Bicultural Challenges for Educational Professionals in Aotearoa. Waikato Journal of Education, (4), pp. 3-16.

Glynn, T., Wearmouth, J., \& Berryman, M. (2006). Supporting Students with Literacy Difficulties: A Responsive Approach. Maidenhead, Berkshire: Open University Press.

Hawtrey, M. J. G. (1840). An Earnest Address to New Zealand Colonists, with Reference to their Intercourse with the Native Inhabitants. London: John W. Parker.

Hawtrey, M. J. G. (1861). Justice To New Zealand, Honour To England. London: Rivingtons.

Jackson, M. (1987). The Maori and the Criminal Justice System, A New Perspective: He Whaipaanga Hou. Part 1. Wellington: Policy and Research Division, Department of Justice.

Jackson, M. (1988). The Maori and the Criminal Justice System, A New Perspective: He Whaipaanga Hou. Part 2. Wellington: Policy and Research Division, Department of Justice.

Jenkins, K. \& Ka'ai, T. (1994). Maori Education: A Cultural Experience and Dilemma for the State - a New Direction for Maori Society. In E. Coxon, K. Jenkins, J. Marshall \& L. Massey (Eds). The Politics 
of Learning and Teaching in Aotearoa-New Zealand, (pp. 148-179). Palmerston North: The Dunmore Press Limited.

Jones, R. (2009). Rongoā - medicinal use of plants - The impact of colonization. In Te Ara - the Encyclopedia of New Zealand. (Updated 2 March, 2009).

URL: $\quad$ http://www.TeAra.govt.nz/en/rongoa-medicinal-use-ofplants $/ 5$

Ka'ai, T. M. (date unknown). Chronology of Significant Events and Key Educational Reforms in Māori Education. Unpublished paper.

Ka'ai, T. M. (1995). Te Tãtari $i$ te Kaupapa. Unpublished PhD. The University of Waikato, Hamilton.

Ka'ai, T. M. (2004). Te mana o te reo me ngā tikanga - Power and politics of the language. In T. M. Ka'ai, J. C. Moorfield, M. P. J. Reilly \& S. Mosley (Eds.), Ki te Whaiao: An Introduction to Mãori Culture and Society, (pp. 201-213). Auckland: Pearson Education New Zealand Limited.

Ka'ai-Oldman, T. (1988). A History of New Zealand Education from a Maori Perspective. In Hirsh, W. \& Scott, R. (Eds.), Getting It Right Aspects of Ethnicity and Equity in New Zealand Education, (pp. 2229). Auckland: The Office of Race Relations Conciliator.

Kawharu, I. H. (Ed.) (1989). Waitangi - Māori and Pākehā Perspectives of the Treaty of Waitangi. Auckland: Oxford University Press.

Kramsch, C. (1998). Language and Culture. Oxford Introductions to Language Study series. (Series Ed. H. G. Widdowson). Oxford: Oxford University Press.

McCarthy, M. (1997). Raising a Māori Child Under a New Right State. In P. Te Whāiti, M. McCarthy, A. Durie (Eds.), Mai i Rangiātea Mãori Wellbeing and Development, (pp.25-38). Auckland: Auckland University Press with Bridget Williams Books.

Merritt, M. R. (1996). Te Matauranga na nga toi whakaaro - Dance and Drama as Education. Unpublished MA. University of Auckland, Auckland.

Moorfield, J. (2006). Teaching and Learning an Indigenous Language Through its Narratives: Māori in Aotearoa/New Zealand. Junctures: The Journal for Thematic Dialogue, (6: Language), June 2006, pp. 107-116.

O'Regan, H. (2006). State of the reo nation: Māori language learning. In M. Mulholland (Ed.), State of the Mãori nation: twenty-first century issues in Aotearoa, (pp. 157-168). Auckland: Reed Books.

Pere, R. T. (1997). Te Wheke: A Celebration of Infinite Wisdom $\left(^{\text {nd }}\right.$ edition). New Zealand: Ao Ako Global Learning New Zealand Ltd. with the assistance of Awareness Book Company Ltd.

Report of the Waitangi Tribunal on the Te Reo Māori Claim (1986)

Smith, G. H. (2000). Protecting and Respecting Indigenous Knowledge. In M. Battiste (Ed.), Reclaiming Indigenous Voice and Vision, (pp. 209-224). Vancouver: UBS Press.

Soanes, C., Spooner, A., \& Hawker, S. (Eds.) (2001). Oxford Paperback Dictionary, Thesaurus, and Wordpower Guide. Oxford: Oxford University Press. 
Te Taura Whiri i te Reo Māori - Māori Language Commission. (date unknown). History of the Māori Language. (Retrieved 16 May, 2010).

URL:

http://www.tetaurawhiri.govt.nz/english/issues_e/hist/index.sht $\underline{\mathrm{ml}}$

Temm, P. (1990). The Waitangi Tribunal - The Conscience of the Nation. Auckland: Random Century New Zealand Limited.

Tonkin, E. (1995). Narrating Our Pasts - The Social Construction of Oral History (first paperback edition). Camberwell: Penguin Group.

United Nations. (date unknown). United Nations Declaration on the Rights of Indigenous Peoples. (Retrieved 24 May 2010).

URL: http://www.un.org/esa/socdev/unpfii/en/drip.html

Walker, R. (1990). Ka Whawhai Tonu Matou, Struggle Without End. Auckland: Penguin Books (NZ) Ltd. 